\title{
RISK FACTORS ON WATER TRANSPORT
}

\section{Valeriia Slatvinskaia ${ }^{1}$ \\ Nikolai Vasilenko ${ }^{2}$}

DOI: https://doi.org/10.30525/978-9934-26-049-0-34

Abstract. The subject of the study is transportation by waterways, in particular, the activity of sea and river transport in conditions of occurrence of unfavorable conditions, the interaction of the ship's crew and the behavior of ship personnel when making decisions on water transport, manifestations of risky events and negative consequences on waterways, decision-making by the boat master in stressful, force majeure, regular and emergency situations.

Methodology. The activity of water transport is inherently a complex system. At the same time, it is even more complex than the organization of IT technologies. Given this, the methodology for studying water transport risk factors is comprehensive. Among the constituent elements, we note: An interdisciplinary approach using the methods of risk theory, Probability Theory, risk management theory, transport law theory, IT law theory, psychology, etc.

The aim of the study is to find out the risk factors inherent in the water transport industry.

Risks in water transport are difficult to predict since foresight is not always an objective category. The objective side of risk in this case is manifested in the fact that it reflects real-life phenomena, processes, and aspects of life. The objective side of risk is since the risk exists regardless of how it is realized, considered, or ignored. The objective side is determined by the probabilistic nature of many processes, and the multivariance of relations. In addition, the risk remains associated with the choice of certain alternatives, calculating the probabilities of their outcome. So, from this understanding it follows that its nature is broader and is associated with

\footnotetext{
${ }^{1}$ Postgraduate Student of the Department of Economic Law and Process,

National University «Odessa Law Academy», Ukraine

${ }^{2}$ Doctor of Physical and Mathematical Sciences, Doctor of Law, Professor, Head of the Department of Cybersecurity,

National University «Odessa Law Academy», Ukraine
} 
the laws of development of the external and internal environment of the organization, as well as with the presence of contradictory trends, imperfection, spontaneity and randomness of events and phenomena. This means that there is and manifests another side of risk - the subjective one. It is obvious because people perceive the same state of risk differently due to different psychological, moral, ideological, religious principles and attitudes. Here, the manifestation of the subjective side is also not in doubt. At the same time, the operation of water transport in a modern economic format requires anticipating and preventing crisis phenomena, reducing the negative consequences of internal and external factors. For an objective assessment of the risks of water transport activities, it makes it necessary to choose effective methods of managing them and requires an adequate scientifically based classification of risks, taking into account the specifics of the functioning of water transport enterprises. The scientific novelty is as follows: for the first time, risk factors in water transport are analyzed; for the first time, it is proposed to consider the behavior and necessary competencies of a ship operator when operating a ship in an emergency situation from the point of view of social engineering; the previously proposed indicative risk factors associated with maritime navigation are supplemented; it is proved that the risks that arise during navigation are fundamentally related to unfavorable living conditions (functioning of the team organization under the sole chairmanship of the captain, as well as his ability and the ability of ship officers to make the right decisions not only in regular situations but also in force majeure conditions (emergency situations). Risks in navigation in emergency situations are caused by dangerous phenomena (force majeure) in the natural, man-made and social environment caused by negative trends in the development of events that lead to dangerous crisis situations when it becomes necessary to take the right actions to overcome the danger.

\section{Introduction}

Transport ensures the development of international economic relations, contributing to a mutually beneficial exchange between different countries. Sea transport was formed as one of the most important components of the economy of a developing state based on a highly developed economic and social base. It ensures the normal functioning of the economy, 
increases the efficiency of social production, creates conditions for the rational placement of production forces on the territory of the country, taking into account the most appropriate approach of enterprises of various sectors of the economy to the sources of raw materials and areas of consumption of products, specialization and cooperation of production, allows you to develop such industries as trade, agriculture. At the same time, transport is a source of increased danger both for humans and for the environment [1, p. 222]. Geopolitical confrontation increases uncertainty, which hinders investment and increases risks in the transport industry interruptions in global supply chains, sudden price fluctuations, failures in the availability of key resources, reduced investment in infrastructure $[2$, p. 24]. The variety of risks of water transport activities and the need to choose an effective method of managing them requires an adequate scientifically based classification of risks, which makes it possible to clearly identify the place of each type of risk in the overall system. Risks are an integral part of the functioning of any enterprise and any activity. Therefore, water transport activities are associated with risks. The problem of the probability of accidents in the port economy and methods of its assessment are relevant both for individual ports and for the state as a whole, because reducing risks and making reasonable decisions will help it function effectively in the international arena.

Currently, risk theory is a deeply developed base of applied mathematics, but it is still not widely used to solve problems related to risk management in sea and river transport. So, for example, in the works [3; [4] the problem of managing certain types of financial risks in the activities of shipping companies and ports is solved, in [5] various organizational and economic problems related to risk management in the activities of maritime transport enterprises are considered. The paper proposes a method for substantiating the feasibility of ensuring the risks of a classification company associated with supplier certification [6, p. 136]. Various national maritime authorities and international organizations have shown great interest in implementing risk management processes in the decision-making process to prevent shipping accidents in Waterway areas. There is a constant need for approaches, models, and tools for identifying, analyzing, and assessing the risks of accidents on sea vessels, as well as strategies for their preventive management in (inter-organizational) conditions [7, p. 1]. 
It is important to stress that the United Nations Maritime Transport survey 2020 focuses on the need for future maritime transport to be calibrated with risk susceptibility in mind and to provide more effective risk management and sustainability capabilities. Understanding vulnerability, vulnerability, and potential losses is key to informing about increased resilience in this sector. At the same time, soon, transport operators should acquire practical skills in risk management in water transport [8, p. xiii].

But there is no comprehensive study of risks in the activities of sea and river transport yet.

The study aims to find out the risk factors inherent in the water transport industry.

Research tasks: to find out the meaning of the concept of «risk in water transport», to identify risk factors inherent in the functioning of sea and river transport.

Research methodology. The current stage of development of the science of transport management is characterized by a focus on enriching the theory and practice of managing complex transport systems with methodological tools of the market economy [9, p. 6]. The activity of water transport is inherently a complex system. At the same time, it is even more complex than the organization of IT technologies. From this, the methodology for studying water transport risk factors is comprehensive. Among the constituent elements, we should note that an interdisciplinary approach using the methods of risk theory, probability theory, risk management theory, transport law theory, IT law theory, psychology, etc.

\section{The concept of «risk» in water transport activities}

Riskology considers risk not only as an undesirable sign of uncertainty about future events but also as a source of positive income opportunities, which in turn generate two types of risks: negative and positive risks. As for the first type, negative risk, then of course it should be avoided, as for the second type - on the contrary, agree, since it carries a positive result. Risks can be considered as a three-dimensional mechanism, for example, risk as a threat, risk as uncertainty, risk as an opportunity. In the first two cases, it is necessary to minimize it, and in the latter case - to optimize it [10, p. 11]. The basis for determining the level of risk in almost all methods is the probability of occurrence of an event that affects the probability of threat 
implementation. In most cases, the probability is determined by the expert method or based on statistics from past periods regarding the same events. However, you should consider the correction for the error of experts, as well as statistics of past periods that may not correspond to previous practice. Moreover, there are more factors influencing the determination of risk than the probability of threat implementation, the amount of losses, and so on. Shipping risks and port risks should also be separated.

It is also logical that due to the fact that the concept of «risk» has a fairly broad interpretation (see $[11 ; 12 ; 13])$ and is well-known, we will find out its features in the activities of sea and river transport. It is also worth noting that risks on Sea and river transport are a type of transport risks - risks associated with the transportation of goods by such modes of transport: road, sea, rail, air. These include accidents and catastrophes [14, p. 70]. Risk in water transport is understood as the probability of occurrence of negative consequences, in particular losses, losses in the process of transportation by waterways.

\section{Major risk factors associated with maritime navigation}

In general, risk can be considered any risk associated with at least one of the four components that are the sources and causes of risks. These include the following components: information; people, technical systems; and nature. At the same time, analyzing sea and river navigation, we note that it is characterized by different degrees of probability of all risk components. In the literature (see [15]), there are attempts to find a generalized term for naming such objects: a sociotechnical system, an object of informatization or automation, and so on. In our opinion, it is quite sufficient to use the term «organization» as an independent object of a specific type of activity. At the same time, firstly, emphasis is placed on the main purpose of the object, and secondly, when it comes to ensuring safety during navigation, it is necessary to consider the entire system and the impact of social engineering on it as an important component of the object's activities. For an organization, we can distinguish at least two aspects of its manifestation: internal object activity and external information manifestation of the object. Considering an organization as an object of a holistic solution to the problem of risks, it is necessary to identify all types of threats that can destructively affect its activities. At least the most likely occurrence of risks during transportation 
by sea. This is since transportation by water modes of transport is the longest of all other types [16, p. 23]. At the same time, risk factors cause threats. A threat represents the degree of possibility of implementing a danger for a given object. Threats to specific objects from the implementation of the danger are characterized by the possibility of exposure to negative factors and causing them harm as a result. The threat to an object from sources of danger is determined by their relative position in space and time (for stationary objects only in space), the distribution of wind directions, the characteristics of the source of danger, the achieved level of protection and stability of objects, and other factors. It is implemented if the object is in the danger zone. Hazards pose a threat to an object only when they can harm it. A threat to objects occurs when their placement in the areas of possible action of negative factors of dangerous natural, man-made and social phenomena [17, p. 97]. In cases of a long time, when there is a lack of initial data or a large complexity of the system, a probabilistic-statistical method is used, rather than a deterministic prediction method. Probabilisticstatistical forecasting methods for scientific prediction are used in such fields as quantum physics, economics, politics, psychology, etc., to predict phenomena in complex systems that are influenced by numerous factors $[18$, p. 475]. In these cases, it is the risk that becomes important. It is difficult to predict risks, since foresight is not an objective category, which cannot be said about risks. It should be noted that the risk also depends on its perception by a particular person, but it can be both objective and subjective, that is, it can be characterized precisely from the positions of these two sides. The objective side of risk is manifested in the fact that it reflects real-life phenomena, processes, and aspects of life. The objective side of risk is because the risk exists regardless of how it is realized, considered, or ignored. The objective side is determined by the probabilistic nature of many processes, and the multivariance of relations. In addition, the risk remains associated with the choice of certain alternatives, calculating the probabilities of their outcome. So, from this understanding it follows that its nature is broader and is associated with the laws of development of the external and internal environment of the organization, as well as with the presence of contradictory trends, imperfection, spontaneity and randomness of events and phenomena. This means that there is and manifests another side of risk - the subjective one. It is obvious since people perceive the 
same risk differently due to different personal principles and attitudes. Here, the manifestation of the subjective side is also not in doubt. We can say that the existence of risk is causally related to the presence of uncertainty, admitting the possibility of its heterogeneity in content and essence.

The marine industry is an example of a large-scale socio-technical system, and there are many implications of coordinating multiple distributed subsystems, such as individual vessels, shoreline operators, and ship traffic service operators, for the functioning of a ship as a common system. The scale of maritime operations also means that the impact on productivity is felt at the systemic level with potentially broad global consequences [19, p. 123].

Here it is appropriate to note about social engineering, which was formed into a science and is the study of human behavior and the factors that affect it. It examines the reasons for the behavior of a particular person and the circumstances and environment that affect the formation of the system of his values and the behavior itself [20, p. 58]. Since the above definition is headed by a person and his behavior, the safe situation created by him becomes important, which manifests itself, first of all, in the risks associated with the activities of the person himself.

The safety of waterways depends on the qualification, psychophysiological characteristics, discipline, experience, and skill [21, p. 60] of ship management. Equipping sea vessels with automated control systems requires a quick response of boat masters in difficult navigation situations, the ability to simultaneously control numerous changing environmental parameters and make decisions when there is a lack of time and necessary information. Despite the fact that on-board automated navigation control systems provide boat masters with information support when controlling a ship in stormy conditions, in the event of an emergency at sea, the crew may not be able to cope with the tasks of controlling the ship, successfully fight for its survivability. As a rule, being in difficult, sometimes critical conditions, the boat master (captain or assistant captain on duty) is in a stressful state and the probability of making the wrong decision increases. Very often, such crews prematurely leave emergency vessels, which in turn worsens the consequences of accidents [22, p. 13]. Since it is almost impossible to establish the exact rules for placing cargo on all vessels, since their design (hull set system) may be different. In this case, 
it is recommended that the ship's Captain be provided with comprehensive information about the load, which allows the cargo to be distributed on the ship in such a way that excessive stresses do not occur in the ship's structures [23, p. 20]. One of the main professional requirements for boat masters set out in the International Convention on training and certification of seafarers and watch keeping, as well as in SOLAS, is knowledge of maritime hazards. The boat master should have a good understanding of all types of sea and weather impacts, not neglect them, but be able to take them into account, avoid or reduce their impact. At the same time, it is useful to follow the rule: it is better to overestimate the danger than to underestimate it (based on the general rule of good maritime practice, consider yourself closer to the danger). In general, there are three groups of types of influence of hydrometeorological factors on the ship: influence on navigation, influence on ship management, influence on the ship as a floating object $[24$, p. 33]. The role of the boat master's in modern realities is not limited only to navigation needs. International maritime organizations, companies and crewing agencies also require the boat master to have the skills of commercial operation of the vessel, competent planning of the transition at all stages in order to obtain maximum profit from cargo transportation in one piece from the port of departure to the port of receipt within the time limits prescribed by the contract. International trade should have a clear maritime character since goods are delivered to the destination countries mainly by sea. However, the global market requires that goods are delivered by sea not only to certain geographical locations, but also in exact time limits, specified volumes and in a preserved form [25, p. 3]. One of the most important aspects of the profession of navigation assistant captain is the planning, construction, and implementation of the route of a sea vessel, the use of combined and innovative methods, research of their effectiveness and effectiveness. Conscious or unintended actions of a person can contribute to the occurrence of a risky event. Even with high-quality information, a specialist can make the wrong decision or perform an unacceptable action that will lead to the implementation of a risky event [26, p. 56].

The problem of risk acceptance and the phenomenon of «risk transit» have several interesting forms of manifestation. A person is more willing to take risks when they are in one-on-one danger and their behavior is open to others. If he is a member of an anonymous group, then each of the group in 
most cases will hope that the risky decision will be made by the other, and as a result, the decision will never be made. If the group is not anonymous, but each of its members is identified, then a surge of initiative will be detected when making a risky decision. A person is more willing to take risks if they understand that there is no one else to solve the problem, that is, they act alone. But if his actions are hidden from others, he will be very tempted to distance himself from the risk.

A person, as a rule, consciously admits a risk factor in their actions. Risky behavior organically follows from the peculiarities of human thinking based on the risk factor. In this regard, the following problem arises: is it possible to increase the effectiveness of decisions made by increasing the intellectual factor of a person's thinking, if he is consciously in a situation of uncertainty or randomness of the results?

One of the paradoxes of the intellectual approach to responsibility for unreasonably risky decisions or actions is that the law enforcement officer is obliged to establish whether the subject could or could not make the optimal decision in a particular situation. However, on an intellectual level, it is simply impossible to prove what a person really could and could not do, and what solution is actually optimal in conditions of changing probability. In this case, under the guise of intellectual analysis of the situation, a personal and subjective assessment of the situation by the law enforcement officer acts.

We emphasize that it is important to make decisions on water transport quickly. This applies to the captain and officers. And it must be correct.

There is a risk of non-compliance with the qualifications of some transport workers and the need to keep up with changing qualification requirements. Changes in qualification requirements are most noticeable in sectors that are highly dependent on the «green» transition, especially in transport [27, p. 62].

There is a penetration of risk into all spheres of human activity, and therefore it is quite difficult to divide risks into types: this process is endless and impractical. However, the risks that arise during navigation are fundamentally related to unfavorable living conditions (functioning of the team organization under the sole chairmanship of the captain, as well as his ability and the ability of ship officers to make the right decisions not only in regular situations, but also in force majeure (emergency situations). Risks in navigation in emergency situations are caused by dangerous phenomena 
(force majeure) in the natural, man-made and social environment caused by negative trends in the development of events that lead to dangerous crisis situations, when it becomes necessary to take the right actions to overcome the danger.

In addition, there are significant risks that are associated with many established forwarding, stevedoring and agency firms that provide handling for the sea delivery of dangerous goods. Their specialists often do not have the appropriate competence for the safe Organization of the transportation process $[28$, p. 113]. To achieve stable positioning in local segments of the maritime trade market, a strategy for responding to the manifestation of a group of operational risks is identified. Among them are possible insolvency of the charterer, force majeure conditions in operator activity and various non-systemic risks, in the structure of the latter, modern piracy using highquality information technologies periodically manifests itself. Therefore, the tools of insurance against possible losses are used [28, p. 117].

The study of practice today shows that in the sphere of functioning of sea and river transport, the occurrence of threats to the safety of navigation is most often affected by: wear and tear of ships, ship, port and other equipment; understaffing of water shipping routes with navigation signs, wear and tear of hydraulic structures; late repair and maintenance work; violation of the rules for storage and transportation of hazardous substances; deviation from project documentation in the production and operation of equipment, technical means; exceeding the standards of transportation of passengers and cargo; understaffing of vessels with life-saving means; violation of safety and labor protection rules; committing offenses and crimes that encroach on safety in the field of water transport; weakening of control over the safety of navigation and in the field of operation of vessels, in connection with the transfer of the latter to private ownership, etc. analysis of accidents reveals a number of main problems that need to be solved by joint efforts of port, regional and state authorities, shipowners, educational institutions and the entire maritime community. First, as before, the main cause of accidents in the navy remains the human factor. This concept refers to incompetence, irresponsibility, inability of sailors to act in difficult situations or fatigue. Secondly, individual captains and shipowners continue to try to hide accidents on ships, which is incomprehensible due to the availability of various insurance programs, which are increasingly 
being implemented in the practice of navigation. In the event of an insured event, all these programs require immediate and complete information about the event to minimize losses. Third, the quality of ship repair and technical operation of ship mechanisms always affects emergency statistics. This problem has become particularly relevant in recent years. Vessels age, mechanisms wear out and require more careful care and highquality repairs. However, the analysis of accidents shows that the level of control, responsibility and professional level of Ship Repair Specialists has decreased in this area of activity. Today, it is necessary to pay more attention to the modernization of navigation equipment of vessels reaching the level of international standards, training of floating personnel in accordance with the requirements of international conventions. Finally decide on the certification of seafarers [29, p. 14].

Ports are strategically important elements of national and international trade. To date, a significant part of the berths of Ukrainian seaports have almost exhausted their standard service life. At the same time, the development of new types of transportation and the emergence of new types of vessels revealed one of the main reasons for the obsolescence of berth structures - to receive new types of vessels, ports need to provide berth depths from 11.5 to $20 \mathrm{~m}$. these circumstances made it necessary to modernize the operated structures. Moreover, further increase in cargo turnover of ports is now impossible without the reconstruction (strengthening) of a certain part of the berthing front or the construction of a new one, which in turn imposes increased requirements for ensuring the reliability of structures. Accordingly, 7 out of 13 seaports in Ukraine are in seismically dangerous areas with a score higher than 7 . Seismic impacts lead to the destruction of Port hydraulic structures and to disruption of the functioning of the port, assessment of seismic impacts and types of failures along with ensuring trouble-free operation of berthing structures [30, p. 23].

The modern world rejected the concept of «absolute» security, due to the impossibility of achieving it, and came to the concept of acceptable (acceptable) risk. ensuring the use of such a level of safety specialists, the use of such organizational and technological schemes, such a state of inland navigation infrastructure facilities, in which the risk of an emergency as a result of the implementation of any technological process does not exceed an acceptable level [31, p. 69]. 
In the activities of a seaport, many different risks may arise associated with the operational activities of individual participants: carriers, charterers, terminal operators, Geodetic companies, insurance companies, customs services, and others [32, p. 210]. The implementation of large investment projects, including concession projects, is always associated with a significant number of risks. Each of the stakeholders of the concession project implemented in the port has its own goals. So, the risks of each of the project participants are different [33, p. 30].

In terms of security, it should be noted that risk is an integral aspect. This category covers the material and legal areas related to the protection of human life and health in the implementation of water transport. In our opinion, the risk in the material direction is the probability of certain adverse events occurring during transportation by water transport, which can lead to material damage or lead to death or harm to human health, regardless of the degree of its participation in the transportation process. As a legal direction, risk is certain benefits and legitimate interests of a person that are protected by the current norms of law and may be violated because of risk situations. Factors of risk occurrence during transportation by water transport can be technical, man-made, human, or natural factors [29, p. 13].

In transport, the risk is associated with the main type of activity - the process of transportation of passengers and cargo, as well as with the performance of loading operations, storage of goods, maintenance and repair of transport equipment, supply of operational materials of production and other processes [34, p. 12]. The main risks in the process of cargo transportation are non - compliance with the rules of cargo preparation and packaging, technical characteristics and serviceability of the vehicle, as well as special equipment of the cargo compartment, the lack of application by the enterprise of rules and standards for marking, loading, placing and securing cargo in the cargo vehicle, and so on.

Having identified to ensure the reliability of bunkering by the safety factor according to the recommendations of international regulatory documents on probabilistic methods of risk assessment risks and their consequences during bunkering, we note that the dangers that have the highest risk are the human factor and faulty equipment [35, p. 12].

Internal source of risks at transport enterprises is unprofitability of activity; accumulation of uncovered losses of previous years; inefficient 
conduct of activities, in which expenses significantly exceed the income received, as well as a high level of depreciation of fixed assets; insufficient capital investment in their restoration; unstable number of employees and the number of economic entities. A powerful source of not only negative phenomena in the economy, socio-political life, but also risks in the activities of transport enterprises is the threat of the spread of COVID-19 [36, p. 132].

Taking into account the peculiarity of water transport, namely: the autonomy of navigation of an individual vessel, it can be argued that during the voyage meteorological factors affect the sailor continuously, that is, both during Watch and during rest. For water transport, especially for vessels traveling on the high seas, Hydrometeorological reasons become a factor in increasing the industrial risk of accidents. Directly due to bad weather conditions, approximately $3.5-5 \%$ of all injuries in the Navy occur. In several accidents, bad weather conditions were associated with other causes of injuries [37, p. 90].

With large-scale use of water vehicles, it is difficult to avoid the occurrence of various emergencies. According to the state service of sea and river transport of Ukraine, during 2019, 30 emergencies occurred on the sea and river transport of Ukraine, including with small (small) vessels, in which 10 people were killed, 10 people were missing and 16 people were injured [38, p. 132].

Operational risk is the risk of an enterprise's activity due to the uncertainty of its condition and functioning under the influence of both external and internal factors [39].

The financial activity of the port in all its forms is associated with numerous risks, the degree of influence of which on the results of this activity increases significantly with the transition to a market economy. The risks accompanying this activity are allocated to a special group of financial risks that play the most significant role in the overall «risk portfolio» of the enterprise [40, p. 132].

It should also be noted that the theory of risk draws attention to the dependence of management decisions made on the nature of the attitude of the management system (the decision maker) to risk, which can be neutral or directly opposite. At the same time, the nature of the attitude to risk in formal terms is determined by the function of the expected effectiveness of decisions made, which (function) can be: linear, associated with a neutral 
attitude to risk; convex, suggesting a predisposition to risk; concave, which corresponds to the absence of risk propensity. This circumstance means that in the case of a neutral attitude to risk, optimization problems can be solved in a deterministic formulation using single-criterion models [41, p. 71].

After forecasting and identifying risks, an analysis and quantitative assessment of risks should be carried out. It is carried out because of calculation and analytical methods and with the involvement of expert assessments. At the same time, it is necessary to consider several factors that are usually divided into fundamental, market and internal. Fundamental risk factors are determined based on an analysis of the political, economic, financial and credit policies of both individual countries and the world community. Conjunctural factors are caused by the presence of a microenvironment, which directly affects the port's operation. Internal factors include factors that characterize the port's investment potential. At the same time, the risk can be assessed by direct and indirect indicators. Direct indicators include growth indices of key economic characteristics (cargo handling volume, net profit, and others). Indirect risk indicators are used when it is impossible to get the values of direct indicators. These include the characteristics of the qualitative state of capital (the intensity of asset turnover, the ratio of borrowed and own funds, asset liquidity, etc.) [40, p. 134].

On waterways there are limiting sections with the smallest overall dimensions (rifts, rapids, channel bends, locks) that limit the size of vessels [42, p. 60]. Navigation in narrow and limited waters is one of the most difficult conditions in which a ship finds itself during operation. Swimming in an area with limited conditions is one of the most difficult types of swimming. It is characterized by the proximity of the vessel to surface and underwater sea navigation hazards, a sharp change in depth, the tortuosity of the fairway, channel or other navigable route, the transience of changes in the environment, as well as restrictions in the speed, draft and maneuvering ability of the vessel. When a vessel moves in shallow water, the main influence on its inertial and braking characteristics is carried out by three factors: an increase in water resistance, an increase in the attached masses and moments of inertia, and a change in the coefficient of influence of the hull on the engine [43, p. 17].

The main risks during transportation are non-payment of freight forwarder services, loss or damage of cargo, delay in delivery of cargo, 
payment for downtime of vehicles, downtime or refusal of cargo at the port of unloading, retention of cargo and documents, damage to cargo during transportation, etc. The main risk factors for cargo damage (for example, cocoa beans) are humidity, water content, condensation, post-fermentation, insect infestation and mold [44, p. 6].

Owners who do not provide cybersecurity for transportation by waterways are not only exposed to such risks but can also detain their vessels by the Port state control authorities, who must ensure compliance with this requirement. Cybersecurity risks are likely to continue to grow significantly because of greater reliance on e-commerce and an increasing shift to virtual interactions at all levels. This increases vulnerabilities around the world, which can potentially lead to devastating consequences and affect the most important supply chains and services [8, p. xiv].

With the advent of rapid technological changes in the marine industry, such as autonomous navigation, which is becoming an increasingly realistic prospect, new risks are constantly emerging [45].

We propose to supplement the previously proposed indicative risk factors associated with maritime navigation [46, p. 47].

The Trade Union of Maritime Transport Workers of Ukraine has joined to the Neptune Declaration on Seafarer Wellbeing and Crew Change.

The Neptune Declaration defines four main actions to improve crew rotation, as well as to maintain the functioning of global supply chains:

recognize seafarers as «key workers» and give them priority access to COVID-19 vaccines;

create and implement a «gold standard» of medical protocols based on existing best practices;

expand cooperation between ship operators and charterers to facilitate crew changes;

provide for seafarers air communication between key sea hubs [47].

Vessels of the degree of risk can be of high, medium, or insignificant degree of risk in accordance with the resolution of the Cabinet of Ministers of Ukraine of July 10, 2019. No. 602 «On approval of the criteria used to assess the degree of risk from carrying out economic activities in the areas of transportation of passengers, dangerous goods, hazardous waste by sea and river transport and safety on Sea and river transport (except for the safety of navigation of vessels of the fishing industry fleet) and determines 


\begin{tabular}{|c|c|c|c|c|}
\hline 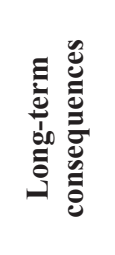 & 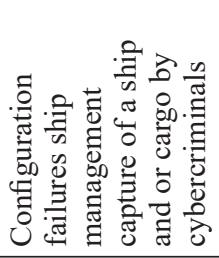 & 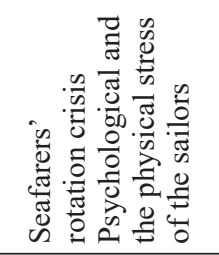 & 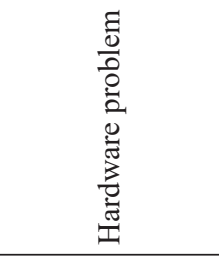 & \begin{tabular}{l}
0 \\
000 \\
\multirow{3}{0}{} \\
4 \\
0 \\
0 \\
0 \\
0 \\
1 \\
1
\end{tabular} \\
\hline 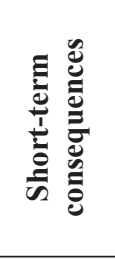 & 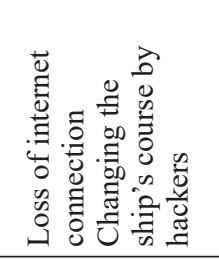 & 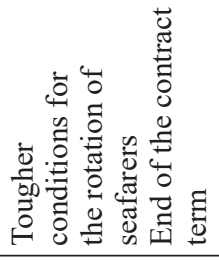 & 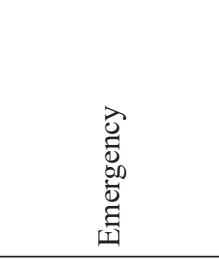 & 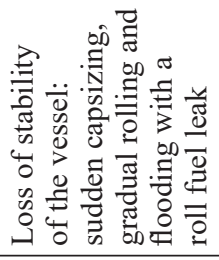 \\
\hline 吾 & 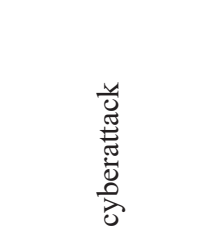 & 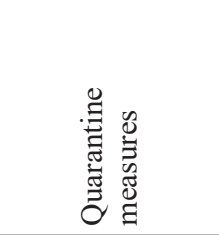 & $\begin{array}{l}\mathscr{\Xi} \\
\infty \\
\tilde{\Xi} \\
0\end{array}$ & 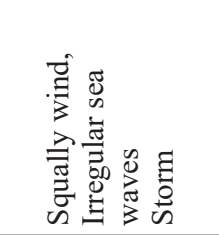 \\
\hline ڤ0 & 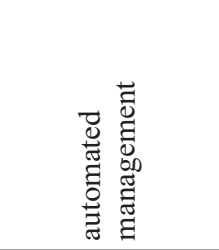 & 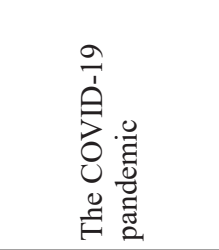 & 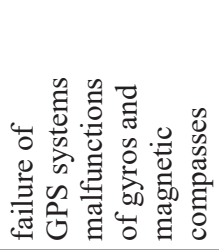 & 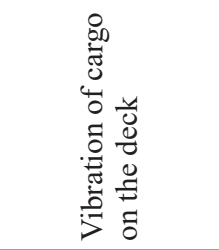 \\
\hline 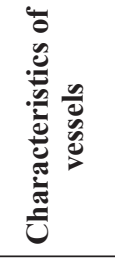 & 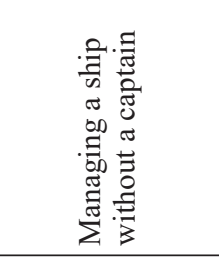 & 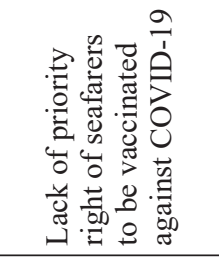 & 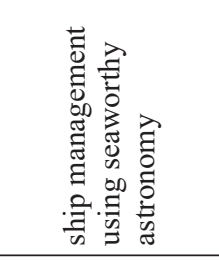 & 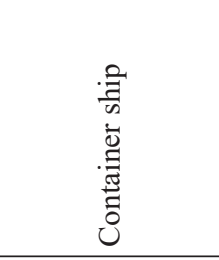 \\
\hline 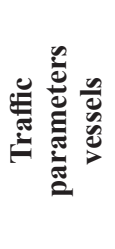 & 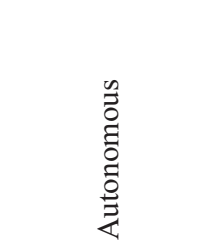 & 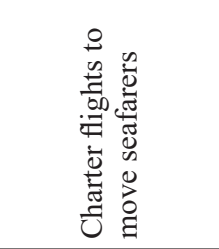 & 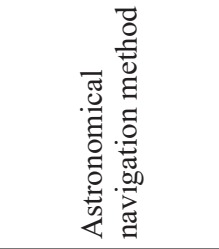 & $\begin{array}{l}\frac{n}{0} \\
0 \\
0 \\
0 \\
0 \\
0 \\
0 \\
0 \\
0\end{array}$ \\
\hline
\end{tabular}


the frequency of planned measures of state supervision (control) by the state service of sea and river transport» [48], resolutions of the Cabinet of Ministers of Ukraine of March 6, 2019. No. 182 «On approval of the criteria used to assess the degree of risk from the implementation of economic activities and determine the frequency of planned measures of state supervision (control) in the field of Environmental Protection, rational use, reproduction and protection of natural resources by the state environmental Inspectorate» [49], resolution of the Cabinet of Ministers of Ukraine of October 31,2018 . No. 895 «On approval of the criteria used to assess the degree of risk from economic activities and determine the frequency of implementation of planned measures of state supervision (control) in the field of maritime safety of vessels of the fishing industry fleet by the state agency for fisheries» [50].

The state of systemic risk is dynamic and can be in a state of low, medium, and high risk. For example, the system is in a safe state at the initial point in time. However, over time, components are likely to lose their efficiency. At the same time, the systemic risk gradually increases from low risk to medium, and then to high [51, p. 7].

\section{Conclusions}

Therefore, it is difficult to predict risks in water transport since foresight is not always an objective category. The objective side of risk in this case is manifested in the fact that it reflects real-life phenomena, processes, and aspects of life. The objective side of risk is since the risk exists regardless of how it is realized, considered, or ignored. The objective side is determined by the probabilistic nature of many processes, and the multivariance of relations. In addition, the risk remains associated with the choice of certain alternatives, calculating the probabilities of their outcome. So, from this understanding it follows that its nature is broader and is associated with the laws of development of the external and internal environment of the organization, as well as with the presence of contradictory trends, imperfection, spontaneity and randomness of events and phenomena. This means that there is and manifests another side of risk - the subjective one. It is obvious because people perceive the same state of risk differently due to different psychological, moral, ideological, religious principles and attitudes. Here, the manifestation of the subjective side is also not in doubt. 
At the same time, the operation of water transport in a modern economic format requires anticipating and preventing crisis phenomena, reducing the negative consequences of internal and external factors.

For an objective assessment of the risks of water transport activities, it makes it necessary to choose effective methods of managing them and requires an adequate scientifically based classification of risks, taking into account the specifics of the functioning of water transport enterprises.

The scientific novelty is as follows:

risk factors in water transport are analyzed for the first time;

for the first time it is proposed to consider the behavior and necessary competencies of a ship operator when operating a ship in an emergency situation from the point of view of social engineering;

the previously proposed indicative risk factors associated with maritime navigation are supplemented.

It is proved that the risks that arise during navigation are fundamentally related to unfavorable living conditions (functioning of the team organization under the sole chairmanship of the captain, as well as his ability and the ability of ship officers to make the right decisions not only in regular situations, but also in force majeure conditions (emergency situations). Risks in navigation in emergency situations are caused by dangerous phenomena (force majeure) in the natural, man-made and social environment caused by negative trends in the development of events that lead to dangerous crisis situations, when it becomes necessary to take the right actions to overcome the danger.

Prospects for further research are to conduct a monographic study of risks in sea and river transport.

\section{References:}

1. Dopilka V. O. (2020). Pravove rehuliuvannia posluh morskoho transportu u sferi turyzmu i mizhnarodnykh podorozhei [Legal regulation of maritime transport services in the field of Tourism and international travel]. Law and society, no. 2(3), pp. 220-225. DOI: https://doi.org/10.32842/2078-3736/2020.2-3.33

2. Tarashevskyi M. (2020). Analiz tendentsii i ryzykiv diialnosti transportnykh pidpryiemstv v Ukraini [Analysis of trends and risks of transport companies ' activities in Ukraine]. Collection of scientific papers $\Lambda^{\prime} O Г O \Sigma$, pp. 24-26. DOI: $10.36074 / 21.08 .2020 . v 1.09$

3. Medvedeva S. A. (2010). Modeli i metody upravleniya finansovymi riskami $\mathrm{v}$ deyatel'nosti morskogo porta [Models and methods of financial risk management in the activities of the seaport]. Dis. Cand. Ekon. Sciences. Odessa: ONMU, 180 p. 
4. Postan M. Ya., Balobanov A.O. (2011). Method of Evaluation of Insurance Expediency of Stevedoring Company's Responsibility for Cargo Safety. Methods and Algorithms in Navigation and Safety of Sea Transportation. A. Weintrit and T. Neumann (eds.). Boca Raton - London - N.Y.: CRC Press, pp. 33-36.

5. Topalov V.P., Torskiy V.G. (2010). Otsenka riska pri ekspluatatsii sudov [Risk assessment in the operation of ships]. Odessa: Astroprint, $128 \mathrm{p}$.

6. Lyubchenko V., Postan M. (2018). Metod obhruntuvannia dotsilnosti strakhuvannia ryzykiv klasyfikatsiinoho tovarystva, pov'iazanykh z sertyfikatsiieiu postachalnykiv [Method of justifying the feasibility of insuring the risks of a classification company related to supplier certification]. Transport development, 1(2), pp. 136-146. https://doi.org/10.33082/td.2018.1-2.13

7. Ketki Kulkarni, Floris Goerlandt, Jie Li, Osiris Valdez Banda, Pentti Kujala (2020). Preventing shipping accidents: Past, present, and future of waterway risk management with Baltic Sea focus, Safety Science, vol. 129. https://doi.org/10.1016/j.ssci.2020.104798

8. Review of maritime transport (2020). United Nations. Geneva, 159 p. Available at: https://unctad.org/system/files/official-document/rmt2020_en.pdf

9. Murad'yan A.O. (2017). Uzghodzhene upravlinnia protsesom perevalky vantazhiv u zahalnotransportnykh vuzlakh [Coordinated management of the cargo transshipment process in general transport hubs]: monograph. Odessa: Kuprienko S.V., 133 p. DOI: $10.21893 / 978-617-7414-07-9.0$

10. Suchasni aspekty nauky: IV-yi tom kolektyvnoi monohrafii [Modern aspects of science: IV-th volume of the collective monograph] (2021) / edited by E. O. Romanenko, I. V. Zhukova. Kiev; Bratislava: FLP Kandyba T. P., 168 p.

11. Vasilenko M. D., Novikov V. P., Rachuk V. A., Slatvinskaia V. M. (2020). Kiberbezpeka $\mathrm{v}$ proiavakh ryzykiv u period pandemii: stan ta heneza [Cybersecurity in the manifestations of risks during a pandemic: state and Genesis]. Bulletin of Cherkasy State Technological University, vol. 3, pp. 30-39. DOI: $10.24025 / 2306-4412.3 .2020 .214774$

12. Vasilenko M., Kozin O. (2019). Pravo v teorii ryzykiv: geneza ryzykiv vid pravovoi do informatsiinoi skladovykh (instytutsiinyi pidkhid) [Law in risk theory: the genesis of risks from legal to informational components (institutional approach)]. Law Herald. Odessa: VD «Helvetica», no. 4, pp. 43-51.

13. Vasilenko M. D., Kozin O. B., Papkovskaya O. B. (2020). Ryzyky: pravova ta informatsiina bezpeka [Risks: legal and information security]. Legal life of Modern Ukraine: in 3 volumes: materials of the International Conference. Nauk.prakt. conf. (Odessa, 15 May 2020) / ed. by M. R. Arakelyan. Odessa: Helvetika, T. 2, pp. 371-374.

14. Dodenko I. (2020). Osnovni ryzyky pidpryiemnytskoi diialnosti z aviaperevezen [The main risks of business activities in air transportation]. Entrepreneurship, economy and law, no. 5. pp. 69-73. DOI: https://doi.org/ $10.32849 / 2663-5313 / 2020.5 .11$

15. Kunanets N.E.,Pasechnik V.V.,FedonyukA.A.(2015). Sotsiokomunikatsiina inzheneriia: ob'iekt, predmet i metody doslidzhennia [Sociocommunication engineering: object, subject and methods of research]. Bulletin of the National University 
"Lviv Polytechnic". Series: Information Systems and networks: collection of scientific papers, no. 829, pp. 374-389.

16. Litvinov O. P. (2020). Spektr ryzykiv v systemi morskykh vantazhnykh perevezen [Range of risks in the system of sea cargo transportation]. University science2020: abstracts of add. Mezhnar. scientific and technical conference (Mariupol, May 20-21, 2020): in 4 volumes / state higher educational institution "PSTU". Mariupol, vol. 3, pp. 23-24. URL: http://eir.pstu.edu/handle/123456789/26690

17. Vishnyakov Ya.D., Radaev N.N. (2008). Obshchaya teoriya riskov [General risk theory], studies. stipend. 2nd edition, ispr. Moscow: Publishing Center "Academy», $368 \mathrm{p}$.

18. Filosofskyi entsyklopedychnyi slovnyk [Philosophical encyclopedia] (2002) / V. I. Shinkaruk (chief editor) and others. Kyiv: Grigory Skovoroda Institute of philosophy of the National Academy of Sciences of Ukraine: Abriz, $742 \mathrm{p}$.

19. Borsh M. V. (2018). The human factor: the concept, the essence of the content, challenges. Materials of the VIII All-Ukrainian Student Science conference [Suchasni problemy morskogo transport ta bezpeka moreplavstva], in 2 t., (Kherson, 22 listopada 2018 roku). Kherson: KHDMA, vol. 1, pp. 122-124.

20. Balandina N. M., Vasilenko M. D., Slatvinskaia V. M., Sysoenko S. V. (2020). Pidkhody modeliuvannia povedinkovykh proiaviv u sotsialnomu inzhynirynhu $\mathrm{v}$ interesakh zakhystu informatsii [Approaches to modeling behavioral manifestations in social engineering in the interests of information protection]. Bulletin of Cherkasy State Technological University. Technical sciences, vol. 4, pp. 57-66.

21. Prikhodko V. I. (2020). Administratyvno-pravova profilaktyka pryhod v Ukraini [Administrative and legal prevention of accidents in Ukraine]. Dissertation for the degree of candidate of Legal Sciences in specialty 12.00.07 "administrative law and process; Financial Law; Information Law". State Research Institute of the Ministry of internal affairs of Ukraine. Kyiv, $282 \mathrm{p}$.

22. Baranenko G. A. (2018). Suchasnyi stan i shliakhy vdoskonalennia orhanizatsii zabezpechennia bezpeky moreplavannia konteinerovoziv [Current state and ways to improve the organization of ensuring the safety of navigation of container ships]. Materials of the VIII all-Ukrainian student scientific conference [modern problems of maritime transport and maritime safety] in 2 volumes, (Kherson, November 22, 2018). Kherson: KHSMU Publishing House, Tom 1, pp. 12-14.

23. Kodeks praktiki dlya bezopasnoy pogruzki i vygruzki sudov, perevozyashchikh navalochnye gruzy (Kodeks BPV) (1998). BLU Code. Code of Practice for the Safe loading and Unloading of Bulk Carriers. London: International Maritime Organization, $72 \mathrm{p}$.

24. Verin V. V., Artyushov S. V., Kudrenko P. S. (2018). Vybir naivyhidnishykh shliakhiv plavannia $\mathrm{z}$ urakhuvanniam hidrometeorolohichnykh umov [Choosing the most favorable sailing routes, considering hydrometeorological conditions]. Materials of the VIII all-Ukrainian student scientific conference [modern problems of maritime transport and maritime safety] in 2 volumes, (Kherson, November 22, 2018). Kherson: KHSMU Publishing House, Tom. 1, pp. 32-35.

25. Nikolaeva L. L. (2006). Komertsiina ekspluatatsiia sudna [Commercial operation of the vessel]: textbook. A.: Phoenix,751 p. 
26. Vasilenko M. D., Matkovskaya I. O. (2020). Deiaki pytannia ryzykiv (informatsiinykh ryzykiv) $\mathrm{v}$ konteksti sotsialnoi inzhenerii [Some issues of risks (information risks) in the context of social engineering]. Security and challenges of our time: risks and cybersecurity during the pandemic security in the modern world: materials of the II All-Ukrainian scientific and practical project. conf. (Odessa, November 20 2020) / edited by O. V. Dikiy. Odessa: "Helvetika publishing house", pp. 53-58.

27. COM (2020). 789 final Commission staff working document Sustainable and Smart Mobility Strategy - putting European transport on track for the future. Available at: https://ec.europa.eu/transport/sites/transport/files/legislation/swd 20200331.pdf (accessed 01 February 2021).

28. Senko O. V, Stakhov A. Yu. (2020). Upravlinnia efektyvnistiu torhovoho sudnoplavstva $\mathrm{z}$ urakhuvanniam systemy ryzykiv [Managing the efficiency of commercial shipping, considering the risk system]. Development of Transport management and management methods, 3(72), 109-120. https://doi.org/ 10.31375/2226-1915-2020-3-109-120

29. Makhmurova-Dishlyuk O. P. (2016). Bezpeka sudnoplavstva yak vazhlyva umova okhorony liudskoho zhyttia [Safety of navigation as an important condition for the protection of human life]. Scientific works of the National Aviation University. Series: legal bulletin "air and space law", vol. 3. no. 40, pp. 11-16. DOI: $10.18372 / 2307-9061.40 .10807$

30. Yehupov, K., Yehupov, V., Murashko, O. (2020). Utochnennia seismichnoho ryzyku ob'iektiv morskoi infrastruktury [Clarification of the seismic risk of marine infrastructure facilities]. Transport development, 2(5), pp. 20-37. https://doi.org/10.33082/td.2019.2-5.05

31. Shakhov, A., Rossomakha, O., Sherstyuk, O., Rossomakha, O. (2020). Ryzyko-oriientovna stratehiia upravlinnia bezpekoiu sudnoplavstva na vnutrishnikh vodnykh shliakhakh Ukrainy [Risk-based strategy for managing the safety of navigation on inland waterways of Ukraine]. Transport development, 2(5), pp. 67-85. https://doi.org/10.33082/td.2019.2-5.01

32. Balobanov O.O., Postan M. Ya. (2020). Some problems of risk-managenet in sea port activity. Development of Scientific Schools of Odessa National Maritime University: collective monograph. Riga: Izdevnieciba "Baltija Publishing", 490 p. https://doi.org/10.30525/978-9934-588-86-0.11

33. Shakhov, A., Piterska, V., Sherstiuk, O., \& Botsaniuk, V. (2020). Mekhanizmy ryzyko-oriientovanoho upravlinnia kontsesiinymy proiektamy v morskykh portakh [Mechanisms of risk - based management of concession projects in seaports]. Transport development, 1(6), pp. 30-39. https://doi.org/10.33082/ td.2020.1-6.03

34. Tkachenko I. O. (2017). Ryzyky u transportnykh protsesakh [Risks in transport processes]: textbook; Kharkiv. Nats. UN-t Misk. Beketov farm. Kharkiv: A. N. Beketov KHNUMG, 114 p.

35. Tymoshchuk O. M., Melnik O. V. (2020). Doslidzhennia bezpeky bunkeruvannia na vodnomu transporti [Research of bunkering safety in water transport]. Water transport: collection of scientific papers, vol. 1(29), pp. 5-14. doi.org/10.33298/2226-8553/2020.1.29.01 
36. Tarashevsky M. M. (2020). Stan upravlinnia ryzykamy na transportnykh pidpryiemstvakh Ukrainy [State of risk management at transport enterprises of Ukraine]. Business Inform, no. 8, pp. 125-133. https://doi.org/10.32983/2222-4459-2020-8-125-133

37. Veligdan N. V., Dashutina L. O., Turchina S. G. (2019). Upravlinnia ryzykamy pry zdiisnenni mizhnarodnykh perevezen vodnym transportom [Risk management in international water transport operations]. Transport systems and technologies: collection of scientific papers of the State University of infrastructure and technologies, 2019. Kiev: State University of infrastructure and technologies, T. 2, vol. 33, pp. 87-93.

38. Suchasni aspekty nauky [Modern aspects of Science]: Volume III of the collective monograph (2020) / edited by E. A. Romanenko and I. V. Zhukova. Kiev; Bratislava: FLP Kandyba T. P., 197 p.

39. Engalychev O.V. (2005). Sovershenstvovanie sistemy upravleniya operatsionnym riskom na predpriyatii [Improving the operational risk management system at the enterprise]. Dis. ... Candidate of Economic Sciences. MSTU, 174 p.

40. Versanova G. A. (2019). Upravlinnia finansovymy ryzykamy portu. Rozvytok metodiv upravlinnia ta hospodariuvannia na transporti [Managing the port's financial risks]. Development of Transport Management and management methods, 1(66), 137-146. https://doi.org/10.31375/2226-1915-2019-1-137-146

41. Muradian A., Rusanova S. (2018). Optymizatsiia uzghodzhenoho upravlinnia protsesom perevalky vantazhiv u transportnykh vuzlakh v umovakh ryzyku [Optimization of coordinated management of the cargo transshipment process in transport hubs under risk conditions]. Transport development, 2(3), pp. 62-74. https://doi.org/10.33082/td.2018.2-3.07

42. Shcherbina O. V. (2018). Orhanizatsiia roboty barzhebuksyrnykh suden u transportno-tekhnolohichnii systemi [Organization of operation of barge towing vessels in the transport and technological system]. Dissertation for the degree of candidate of technical sciences in the specialty 05.22.01 - transport systems. Odessa National Maritime University. Odessa, 218 p.

43. Shemonaev V. Yu. (2020). Praktychni osoblyvosti upravlinnia sudnamy pry plavanni v obmezhenykh vodakh ta vuzkostiakh [Practical features of ship management when sailing in limited waters and narrow areas]. Young scientist, no. 2(78), pp. 17-23. DOI: https://doi.org/10.32839/2304-5809/2020-2-78-4

44. Yilmaz Uygun \& Syed Asad Imam Jafri (2020). Controlling risks in sea transportation of cocoa beans. Cogent Business \& Management, 7:1, 1778894, 15 p. DOI: $10.1080 / 23311975.2020 .1778894$

45. Jalonen R., Tuominen M. (2017). Wahlström Safety of Unmanned Ships Safe Shipping with Autonomous and Remote Controlled Ships Aalto University Publication Series Science + Technology 98 p.

46. Kerivnytstvo MAMS № $1018 \mathrm{z}$ upravlinnia ryzykamy [MAMS risk management guide No. 1018] (2008). Edition 2 (December 2008). Available at: https://hydro.gov.ua/dl/iala/ua/03_1018_MAMS_vol_1.pdf(accessed 01 February 2021).

47. The Neptune Declaration on Seafarer Wellbeing and Crew Change. 2021. Available at: https://www.globalmaritimeforum.org/content/2020/12/The-NeptuneDeclaration-on-Seafarer-Wellbeing-and-Crew-Change.pdf (accessed 01 February 2021). 
48. Resolution of the Cabinet of Ministers of Ukraine of July 10, No. 602 (2019). Pro zatverdzhennia kryteriiv, za yakymy otsiniuietsia stupin ryzyku vid provadzhennia hospodarskoi diialnosti u sferakh perevezennia pasazhyriv, nebezpechnykh vantazhiv, nebezpechnykh vidkhodiv morskym i richkovym transportom ta bezpeky na morskomu ta richkovomu transporti (krim sfery bezpeky moreplavstva suden flotu rybnoi promyslovosti) ta vyznachaietsia periodychnist provedennia planovykh zakhodiv derzhavnoho nahliadu (kontroliu) Derzhavnoiu sluzhboiu morskoho ta richkovoho transportu [On approval of criteria by which the degree of risk from carrying out economic activities in the areas of transportation of passengers, dangerous goods, hazardous waste by sea and river transport and safety on Sea and river transport (except for the sphere of maritime safety of vessels of the fishing industry fleet) is assessed and the frequency of planned measures of state supervision (control) by the state service of sea and river transport is determined]. Available at: https://zakon.rada.gov.ua/laws/show/602-2019-\%D0\%BF\#Text (accessed 01 February 2021).

49. Resolution of the Cabinet of Ministers of Ukraine No. 182 of March 6 (2019). «Pro zatverdzhennia kryteriiv, za yakymy otsiniuietsia stupin ryzyku vid provadzhennia hospodarskoi diialnosti ta vyznachaietsia periodychnist provedennia planovykh zakhodiv derzhavnoho nahliadu (kontroliu) u sferi okhorony navkolyshnoho pryrodnoho seredovyshcha, ratsionalnoho vykorystannia, vidtvorennia i okhorony pryrodnykh resursiv Derzhavnoiu ekolohichnoiu inspektsiieiu» [On approval of criteria used to assess the degree of risk from economic activities and determine the frequency of planned measures of state supervision (control) in the field of Environmental Protection, rational use, reproduction and protection of natural resources by the state environmental Inspectorate]. Available at: https://zakon.rada.gov.ua/laws/show/182-2019-\%D0\%BF\#Text (accessed 01 February 2021).

50. Pro zatverdzhennia kryteriiv, za yakymy otsiniuietsia stupin ryzyku vid provadzhennia hospodarskoi diialnosti ta vyznachaietsia periodychnist zdiisnennia planovykh zakhodiv derzhavnoho nahliadu (kontroliu) u sferi bezpeky moreplavstva suden flotu rybnoi promyslovosti Derzhavnym ahentstvom rybnoho hospodarstva» [On approval of criteria used to assess the degree of risk from economic activities and determine the frequency of implementation of planned measures of state supervision (control) in the field of maritime safety of vessels of the fishing industry fleet by the state agency for Fisheries»] (2018). Resolution of the Cabinet of Ministers of Ukraine No. 895 of October 31. Available at: https://zakon.rada.gov.ua/ laws/show/895-2018-\%D0\%BF\#Text (accessed 01 February 2021).

51. Wang, Siqi \& Yin, Jingbo \& Khan, Rafi Ullah (2020). The MultiState Maritime Transportation System Risk Assessment and Safety Analysis. Sustainability, 12(14). 10.3390/su12145728. 